\title{
Developing Monopoly Educational Game Application on XI Grade High School Student's About Cell Teaching Material
}

\author{
Restiana $^{1 *}$, Djukri $^{2}$, Indarto $^{3}$, Umi Hijriyah ${ }^{3}$ \\ ${ }^{1}$ Biology Education, Postgraduate Program, Yogyakarta State University, Jl. Colombo No. 1, Karang Malang, \\ Yogyakarta, 55281, Indonesia \\ ${ }^{2}$ Biology Education, Faculty of Mathematics and Natural Science, Yogyakarta State University, Jl. Colombo No. 1, \\ Karang Malang, Yogyakarta, 55281, Indonesia \\ ${ }^{3}$ Raden Intan State Islamic University Lampung, Sukarame, Bandar Lampung \\ *Corresponding author. Email: resti4300@gmail.com
}

\begin{abstract}
This study explains the process of developing a monopoly educational game application on XI grade high school students about Cell teaching material and determining the feasibility and quality of the product. This research categorized as developing by Borg and Gall with six stages of research. Those are research and collecting information, planning, developing preliminary forms of product, preliminary field testing, main product revision and main field testing. Then, the research population was on the YP UNILA Bandar Lampung high school students. The sample used was 20 students of XI grade MIA for the limited scale test and 33 students of XI grade MIA for the broad-scale test. Determination of the sample using a purposive sampling technique. Data were collected through a feasibility questionnaire for media specialists, teaching material experts and linguists, and teacher and student response questionnaires. The data were analyzed by descriptive quantitative and descriptive qualitative. The research results showed that the percentage of media expert was $88.60 \%$, teaching material experts $81.25 \%$, linguists $78 \%$, teacher responses $89.06 \%$ and student responses $88,10 \%$. Therefore, the monopoly educational game application is proper to be used as a teaching medium and ease students to understand the material.
\end{abstract}

Keywords: Learning media, Educational game application, Monopoly.

\section{INTRODUCTION}

Biology science explains all daily life aspect. Students often experience difficulties in studying biology because they memorize too many foreign terms [1]. One of the biological materials that have many biological foreign terms is cell teaching material. Cell teaching material consists of sub-theories, the structure of the cell and its functions. The research results at SMA YP Unila Bandar Lampung showed that student teaching outcomes on cell teaching material were still low. It scores below the minimum school completeness criteria, namely 70 .

The teacher delivers the teaching material and supports, activates, and invites students to be vibrantly involved in the teaching process. Teachers can trigger students' interest in understanding and receiving teaching material by utilizing teaching media [2] [3].

Teaching media overcome boredom during the teaching process [4]. Teachers can adjust their teaching media based on student characteristics and technological developments. The use of technology is an important factor for effective teaching. It can trigger positive student behaviour in the teaching process [5]. Teaching media that are fun, interesting, effective and studentcentred make students more enthusiast. These teaching media are called educational games. The use of games in the teaching process can trigger student interest in teaching. There are challenging rewards and punishments in these games to feel challenged to learn [6]. Educational games have several advantages, such as fun, entertaining, allowing students' enthusiastic participation to learn, providing direct feedback, and minimize students' the rejects in teaching [7] [8].

A game that is easily modified by presenting biology teaching material is a Monopoly game. Monopoly game is friendly to use. This game is familiar to society, especially among teenagers [9]. Based on several studies 
that have been conducted, the use of monopoly media provides opportunities for students to explore their ability to think [10]. Monopoly games encourage students to be more vibrant [11]. Monopoly games help students learn independently and achieve teaching goals [7]. Monopoly games can improve concept mastery [12], teaching motivation and collaboration between students in developing their abilities to create a vibrant teaching atmosphere. The vibrant teaching atmosphere can improve student teaching outcomes.

According to Asna Maghfirah's research, it is concluded that monopoly games are useful for improving student teaching outcomes on excretion material. It is proved by the high posttest results of the experimental class using monopoly game media. Compared to the control class, which does not use monopoly game media [13]. Research by Tresna concluded that the monopoly game is feasible for various teaching media on the hormone system material as proven by a feasibility questionnaire [1]. Research by Khalifa Ulfa concluded that monopoly game media affected the conceptual understanding of eighth-grade students. It is about the digestive system teaching material, as evidenced by the increase in students' posttest scores after applying monopoly game media [12]. Based on this research, no one develops monopoly game media on cell teaching material and develops it in an android application. Therefore, this statement is used as the purpose of this research and development.

\section{RESEARCH METHOD}

The research type is research and development by Borg and Gall [14] consist of 6 stages. Those are research and collecting information (conducting field studies or observations to determine the teaching process's potential problems). Planning/designing research and development in order to find solutions to problems in the teaching process. Then, develop preliminary forms of products (developing products from the results of planning and then conducting due diligence by media specialists, teaching material experts and linguists), preliminary fields testing (limited product trials using $20 \mathrm{XI}$ grade students), main product revision (revising the results of limited product trials), and main field testing (wide-scale product trials using 30 class XI students).

\subsection{Location and Time}

The research was conducted at SMA YP UNILA Bandar Lampung in 2017.

\subsection{Subject of Research}

The study population was the YP UNILA Bandar Lampung high school students. The sample used was 20 XI grade MIA students for limited scale trials and 33 XI grade MIA students for wide-scale trials. Sampling was conducted using a purposive sampling technique, selecting students using android for easy distribution and access to applications.

\subsection{Data Collection Technique}

The data collection instrument was a feasibility questionnaire for media, material and language experts, and a biology teacher and student response questionnaire. Data obtained from the validation of a questionnaire from media, material and language experts, and the results of biology teachers and students' responses.

\subsection{Data Analysis Technique}

Data were analyzed descriptive-quantitatively based on the questionnaire results and qualitative descriptive based on experts' suggestions and suggestions. The validation and questionnaires response use a Likert scale for scoring as in table 1. below:

Table 1. Likert scale

\begin{tabular}{|c|c|c|}
\hline No. & Quantitative Analyze & Score \\
\hline 1. & Very good & 4 \\
\hline 2. & Good & 3 \\
\hline 3. & Not too good & 2 \\
\hline 4. & Very Not too good & 1 \\
\hline
\end{tabular}

The data were analyzed by finding the percentage value of the questionnaire assessment for each item using the following formula:

Percentage of eligibility value $=\frac{\text { obtained score }}{\text { Maximal score }} \times 100 \%$

The percentage of eligibility score obtained is interpreted into a scale of eligibility criteria based on table 2. below:

Table 2. Eligibility criteria scale

\begin{tabular}{|c|c|c|}
\hline No. & Pencentage $(\%)$ & Interpretation \\
\hline 1. & $\mathrm{p}>80 \%$ & Very Qualified \\
\hline 2. & $61 \%<\mathrm{p} \leq 80 \%$ & Qualified \\
\hline 3. & $41 \%<\mathrm{p} \leq 60 \%$ & Qualified Enough \\
\hline 4. & $21 \%<\mathrm{p} \leq 40 \%$ & Less Qualified \\
\hline 5. & $\mathrm{p} \leq 21 \%$ & Very less Qualified \\
\hline
\end{tabular}

The monopoly educational game application is proved feasible if the percentage of eligibility is $\geq 61 \%$ [15].

\section{RESULTS AND DISCUSSION}

This study uses a research and development model that refers to the Borg and Gall procedure. The research and development stages are limited to stage six, namely: research and collecting information (making observations in school to find out the potential problems faced by students during the teaching process and have 
an impact on teaching outcomes), planning (Research plan in developing products that will be solutions in overcoming problems) in school), develop preliminary forms of the product (develop products from the results of planning, and they are assessed for their feasibility by media specialists, teaching material experts and linguists), preliminary field testing (conducting limited product trials using $20 \mathrm{XI}$ grade students), main product revision (improving based on student responses to limited product trials) and main field testing (conducting wide-scale product trials in $30 \mathrm{XI}$ grade students).

\subsection{Research and Collecting Information}

The problems faced in the teaching process of biology subject, especially in cell teaching material at SMA YP UNILA Bandar Lampung, are related to the teaching media used. During the teaching process, the teacher uses less attractive media to decrease student interest in teaching and impacts low student teaching outcomes. Students need fun teaching media. Then, it can trigger student interest in teaching and improve teaching outcomes.

\subsection{Planning}

Based on the problems stated above, planning the products that will be developed and adapted to the students need. Monopoly game is chosen because it can provide fun and motivation in student teaching behaviour [6]. Producing monopoly teaching media that suit student needs and provides benefits as teaching media is necessary to design a product. Those are such as 1) Determining the number of boxes to be used in the monopoly educational game application, including the "start" box, the box " cell organelle "," chance card "box," general points "box," pictorial question "box," passing only "box," question free "box," and "prison" box totalling 36 boxes, 2) Searching for images of organelles cells such as ribosomes, endoplasmic reticulum, lysosomes, Golgi bodies and place in a predetermined box, 3) Make 64 questions related to cell teaching material with cognitive levels $\mathrm{C} 1, \mathrm{C} 2, \mathrm{C} 3, \mathrm{C} 4$, C5 and C6, 4) Determining the duration of time to answer each question, 5) Determining the starting point of the player, adding points for correct answers, subtracting points for wrong and non-answering answers, 6) Determining the player character to be used, 7) Designing game rules and guidelines for how to play, 8 ) Determining the size of the application and 9) Select the tone used.

\subsection{Develop a Preliminary Form of Product}

The product is developed using Adobe Flash Professional CC 2015 and Adobe Photoshop CC 2015. Adobe Flash Professional CC 2015 is used in making programs such as insert coding for accessing this application. The use of adobe flash in the development of this application is 1) moving the player character to move places, 2) rolling the dice and generating dice randomly, 3) bringing up each instruction when the player lands on a particular box, 4) setting the game music on-off, 5) set the duration of the game, 6) set substitutions and others. Meanwhile, Adobe Photoshop CC 2015 is used in designing parts of monopoly games such as "chance cards", "general point cards" and others. Adobe Photoshop's use makes the monopoly educational game application developed to have a harmonious composition of writing, colours, and images. The results of the development produce an android game application which can be seen in Figures 1 and 2 below:

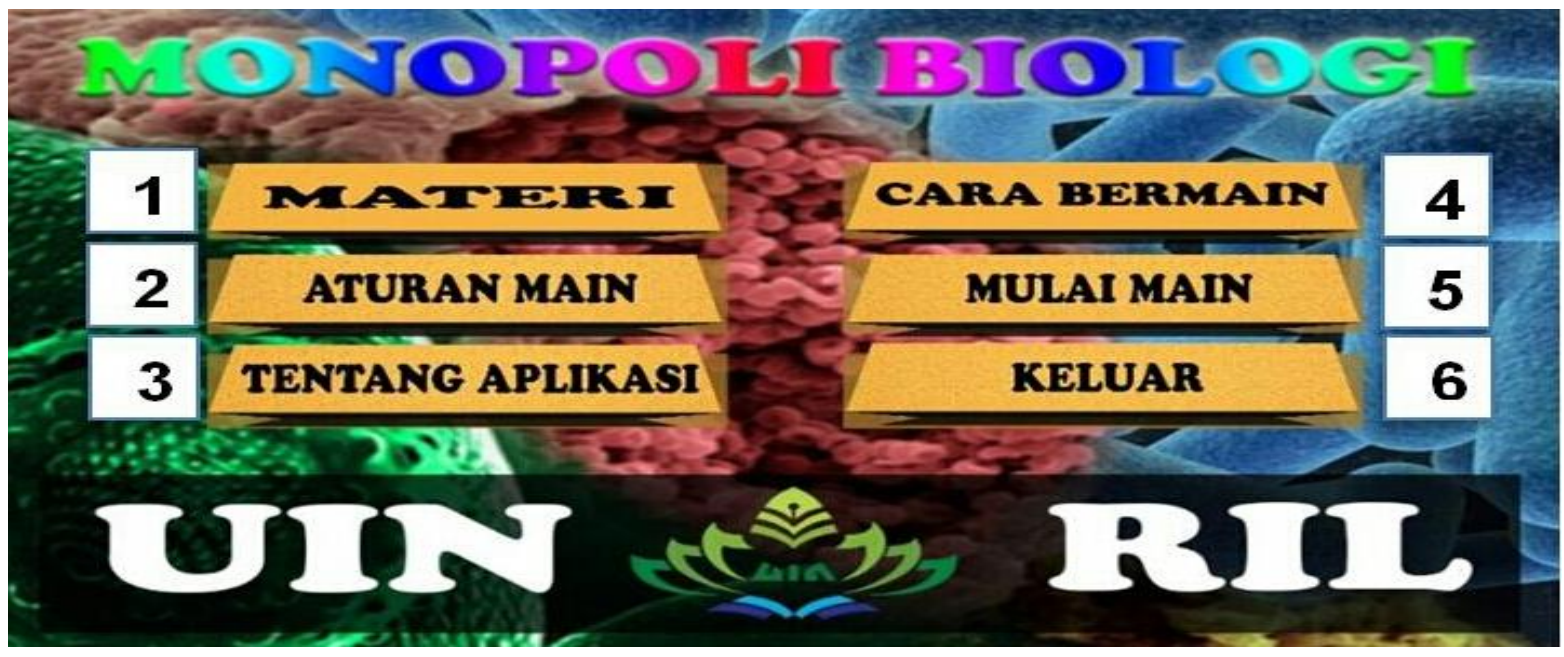

Figure 1. The initial view of the product

Figure 1 shows the initial part that will appear after the user opens the Android-based monopoly educational game application. This section has several explanations, namely: 1) Teaching material in monopoly contains cell teaching material complemented by pictures. This cell teaching material can be studied before students play. It used to answer questions when starting to play this game, 2) Rules of the game contain a description of the 
rules applied to each monopoly game box, 3) About the application, contains a description of the application being developed, 4) How to play contains instructions about how to play this game, 5) Start playing, containing the monopoly board game that is ready to be played and 6) Exit, if the player wants to quit/end the game.

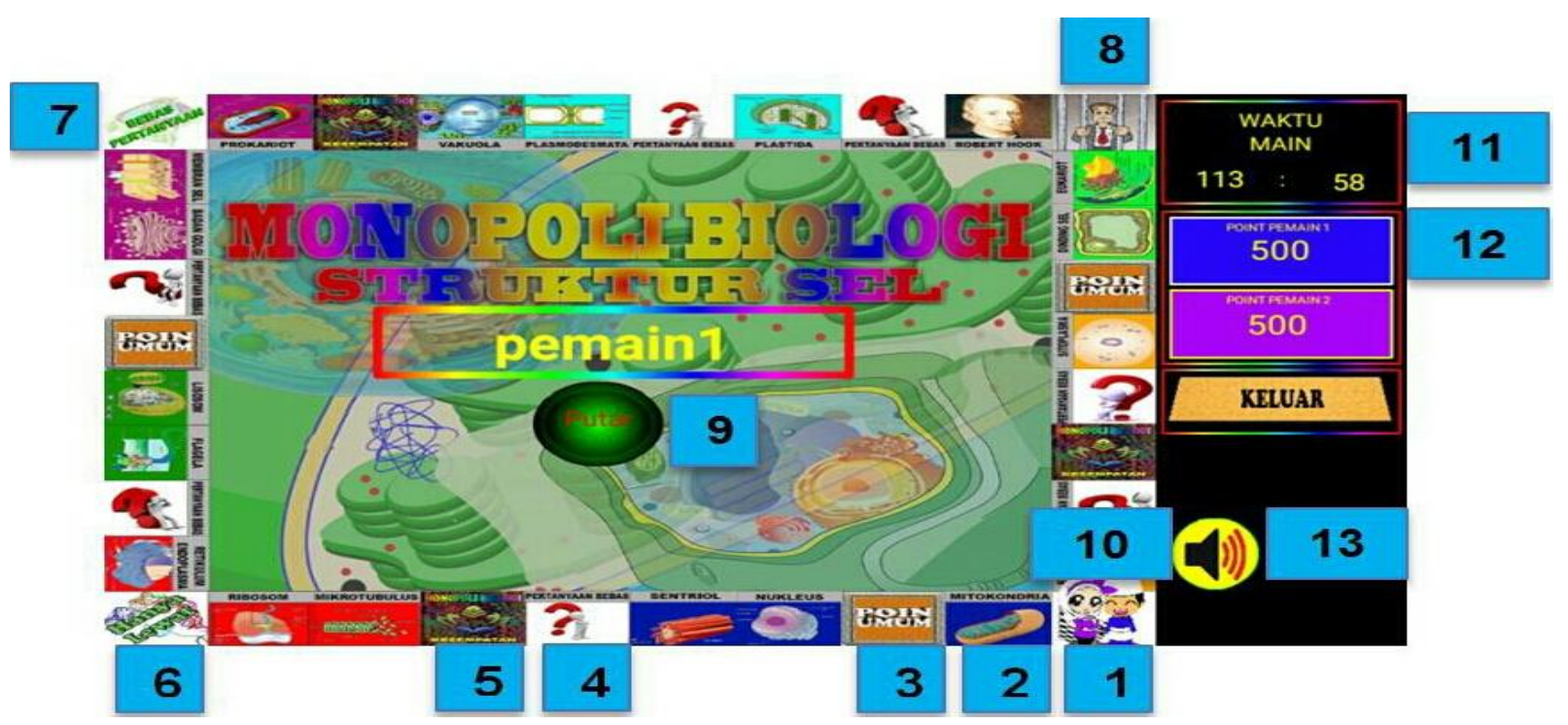

Figure 2. Display of the monopoly game board

Figure 2 shows part of the board game of an android based monopoly educational game application. The method of playing a monopoly based on android is the same as playing the traditional monopoly. Besides, it is just developed in certain parts according to its intended use. These parts are described as follows:

1. The start box is the starting line for the player to start the game.

2. Organelle box contains images of cell organelles such as the endoplasmic reticulum, ribosomes, lysosomes, Golgi bodies, and others. This box will provide questions related to cell teaching material to be answered when landing in the box. Each organelle contains three questions. If the player answers correctly, there will be additional points, and the box will become the players' owner. In contrast, if the player answers wrong, there will be a point deduction.

3. General point box, is a box containing the rules of points that occur when a player lands on the box, such as 1) getting 40 points, 2) points will be reduced by 40,3 ) getting 80 points from opponents and 4) giving as much as 80 points to the opponent.

4. Free question box is a box containing questions related to cell teaching material which is complemented with pictures.

5. The chance card box is a box containing several instructions that must be carried out by the player who lands on the box such as 1) go to start, 2) go to the ribosome box, 3) move back three boxes, 4) go two boxes ahead and 5) go to jail.

6. The box only passes, if the player lands on this box, then it does not get any treatment.

7. Question-free box, if the player lands on this box, then the player is free from questions and does not get any treatment.

8. Jail box, if the player lands on this box, there will be a point reduction.

9. Dice, two dice are used. If the number 6 appears on both dice, the player has the chance to roll back to continue the game.

10. Two players, this monopoly game application, can be used by two students.

11. Playing duration. The players are given the duration to answer questions that appear for 2 minutes. If the player does not answer, then there is a point reduction.

12. The starting point, the initial point given is 500 points. Points will decrease and increase as they play.

13. The tone of the game. There is a tone that can be heard during the game, so the student does not feel bored. The tone can also be disabled.

The validation results by 6 experts consisting of 2 media specialists, 2 teaching material experts, and 2 linguists aim to determine the product's feasibility before being tested. Assessment by media specialists gives value to the visual aspects, effectiveness, and product presentation. The teaching material expert assesses the content of the cell teaching material. The linguist assesses the suitability of terms and the accuracy of writing punctuation on the material. Product assessment obtained quantitative data in the form of numbers and qualitative data in criticism and suggestions. Quantitative data from product validation results are presented in table 3 below: 
Table 3. Product validation result

\begin{tabular}{|c|c|c|c|c|}
\hline No. & Expert & \multicolumn{2}{|c|}{ Score } & Percentage (\%) \\
\hline \multirow{2}{*}{1.} & \multirow{2}{*}{$\begin{array}{l}\text { Teaching Material Feasibility } \\
\text { a. Content Aspect }\end{array}$} & $\sum \mathrm{M} 2$ & $\sum \mathrm{M}$ & \multirow{2}{*}{81,25} \\
\hline & & 78 & 96 & \\
\hline \multirow{2}{*}{2.} & \multirow{2}{*}{$\begin{array}{l}\text { Linguist } \\
\text { a. Language Aspect }\end{array}$} & $\sum \mathrm{B} 2$ & $\sum \mathrm{B}$ & \multirow{2}{*}{78} \\
\hline & & 50 & 64 & \\
\hline \multirow{4}{*}{3.} & \multirow{4}{*}{\begin{tabular}{ll}
\multicolumn{2}{l}{ Media expert } \\
a. $\quad$ Display Aspect \\
b. & Programming Aspect \\
& Total Media Expert
\end{tabular}} & $\sum \mathrm{D} 2$ & $\sum \mathrm{D}$ & \multirow{2}{*}{89,50} \\
\hline & & 86 & 96 & \\
\hline & & 70 & 80 & 87,50 \\
\hline & & 156 & 176 & 88,60 \\
\hline \multicolumn{2}{|r|}{ Overall } & \multicolumn{3}{|c|}{$82,61 \%$} \\
\hline
\end{tabular}

Note:

$\sum \mathrm{M} 2=$ number of each aspect

$\sum \mathrm{M}=$ maximum score

$\sum \mathrm{B} 2=$ number of each aspect

$\sum \mathrm{B}=$ maximum score

$\sum \mathrm{D} 2=$ number of each aspect

$\sum \mathrm{D}=$ maximum score

The data above shows that teaching material expert validation on appropriate content gets $81.25 \%$ (very feasible). The assessed content's feasibility aspect is related to the suitability between the cell teaching material presented in the monopoly educational game application and the cell teaching material presented in its teaching process. The linguist validation results on the language's feasibility aspect obtained 78\% (feasible). The aspect of language feasibility assessed is related to foreign terms' suitability considering that biological material contains many foreign terms. It also assesses the accuracy of writing punctuation on the material. The results of the media specialist's validation on the display and programming aspects obtained a percentage of $88.60 \%$ (very feasible). The display assessed between the suitability composition such as size, type and colour of the letters with the background. Then, the suitability between the quality and size of the displayed image. The programming aspect that was assessed was the ease of using the product. By obtaining this value, it can be concluded that the overall results of expert validation obtained a percentage of $82.61 \%$ (very feasible). The experts' feasibility with a high percentage gain shows that the monopoly educational game application is declared feasible. Then, it needs to be tried to get other product quality responses.

Qualitative data in the form of criticism and suggestions given by experts as material for improvement are presented in table 4 below:

Table 4. Product improvements

\begin{tabular}{|c|c|c|c|}
\hline No. & Expertise & Critics and suggestions & Revision \\
\hline \multirow[t]{3}{*}{1.} & \multirow[t]{3}{*}{ Media Expert } & $\begin{array}{l}\text { Improvements to the font type and text } \\
\text { background in the "organelle" box are } \\
\text { adjusted so that the text is legible }\end{array}$ & $\begin{array}{l}\text { Change the text's background colour in the } \\
\text { "organelle" box to a neutral colour so that } \\
\text { the text can be read. Bright background } \\
\text { colour composition will reduce image } \\
\text { quality. [16] The choice of type and font, } \\
\text { the background colour, significantly } \\
\text { influences someone's reading interest [17]. }\end{array}$ \\
\hline & & $\begin{array}{l}\text { Replace the current logo with the university's } \\
\text { newest logo. }\end{array}$ & $\begin{array}{l}\text { Replace the appearance of the university's } \\
\text { newest logo. }\end{array}$ \\
\hline & & $\begin{array}{l}\text { Improvements to the "question-free box } \\
\text { design". }\end{array}$ & $\begin{array}{l}\text { Make changes to the design of the } \\
\text { "question free" box to make it simpler. }\end{array}$ \\
\hline 2. & Teaching material expert & $\begin{array}{l}\text { Add descriptions and images that support cell } \\
\text { content. }\end{array}$ & $\begin{array}{l}\text { Add a description of the cell teaching } \\
\text { material to be more detailed and equipped } \\
\text { with images to clarify the material. Adding } \\
\text { an image to the content can highlight an } \\
\text { event. The use of pictures can also motivate } \\
\text { students to read [18]. }\end{array}$ \\
\hline 3. & Linguist & $\begin{array}{l}\text { Improvements in writing foreign terms in } \\
\text { sentences. }\end{array}$ & $\begin{array}{l}\text { Improve the writing of foreign terms in } \\
\text { sentences according to applicable } \\
\text { regulations. }\end{array}$ \\
\hline
\end{tabular}


The product assessment given by the biology teacher consists of several aspects, namely content aspects, quality aspects, effectiveness aspects and presentation aspects. The indicators assessed in the content aspect include the material's suitability with core competencies, necessary competencies and teaching objectives. The quality aspect assesses several indicators related to product quality by the media's provisions, design quality, and product use quality. The aspects of effectiveness assessed are several indicators related to the product's benefits as an interactive, fun media, increasing student independence and following teaching needs. Meanwhile, the presentation aspect assesses several indicators such as the suitability of images with the material, clarity of instructions for use and ease of selecting the application menu. In general, the assessment can be seen in table 5 below:

Table 5. Teachers response results

\begin{tabular}{|c|c|c|c|}
\hline Aspects & $\sum \mathrm{T} 2$ & $\sum \mathrm{T}$ & 32 \\
\hline Content Aspect & 26 & 24 & 81,25 \\
\hline Quality Aspect & 21 & 32 & 87,50 \\
\hline Efectivity Aspect & 31 & 40 & 96,88 \\
\hline Presentation Aspect & 36 & 128 & 90 \\
\hline Total & 114 & 89,06 & \\
\hline
\end{tabular}

Note:

$\sum \mathrm{G} 2=$ the number of each aspect

$\sum \mathrm{G} \quad=$ Maximum Score

Based on table 5, the results of the biology teacher's responses aim to determine the quality and attractiveness of the product. The assessment of teacher responses with the highest percentage was in the effectiveness aspect of $96.88 \%$. The teacher responses' assessment with the lowest percentage was the content aspect related to the material's suitability, obtaining $81.25 \%$. Overall the results of the assessment obtained a percentage of $89.06 \%$. The teacher also gave criticism and suggestion such as; 1) adding teaching indicators and 2) adding pictures to the questions. From the results of the biology teacher's assessment regarding the monopoly educational game application product, it is declared feasible to support teaching.

\subsection{Preliminary Field Testing}

Limited scale product trials used 20 students of class XI MIA SMA YP UNILA Bandar Lampung. Product trials were carried out by sharing the monopoly application via SHARE-it android. Students form pairs to be able to play monopoly. After finishing playing, students are given responses through the provided questionnaire. The results of student responses to the limited trial are presented in table 6:

Table 6. Limited scale product trials

\begin{tabular}{|c|c|c|}
\hline $\begin{array}{c}\text { Total } \\
\text { Respondent }\end{array}$ & $\begin{array}{c}\text { Average } \\
\text { Percentation }\end{array}$ & Criteria \\
\hline 20 & $82,72 \%$ & Very Feasible \\
\hline
\end{tabular}

Based on table 6 , the percentage is $82.75 \%$ (very feasible). Student responses given to monopoly products include several indicators related to product quality. Students need teaching media that is practical, fun and has an attractive appearance design. This application can be played through students' gadget in offline mode. The students can enjoy the game while sharpening their brains with the questions loaded in the game.

\subsection{Main Product Revision}

There was not much input from students in limited product trials but only improved graphic design. Once repaired, the product can be directly tested more widely.

\subsection{Main Field Testing}

Broad-scale product trials using 33 students of class XI MIA SMA YP UNILA Bandar Lampung. The research procedure carried out in large-scale product trials is the same as the limited-scale product trial procedures. The results of student responses to broadscale product trials are presented in table 7 below:

Table 7. Wide-scale product trials

\begin{tabular}{|c|c|c|}
\hline $\begin{array}{c}\text { Total } \\
\text { Respondent }\end{array}$ & $\begin{array}{c}\text { Average } \\
\text { Percentation }\end{array}$ & Criteria \\
\hline 33 & $88,10 \%$ & Very Feasible \\
\hline
\end{tabular}

Based on table 7 , the percentage is $88.10 \%$ (very feasible). Student responses in detail to the monopoly educational game application on each questionnaire indicator are presented in table 8: 
Table 8. Students response result

\begin{tabular}{|c|c|c|}
\hline No. & Aspect & Percentage $(\%)$ \\
\hline 1. & Easy to use & 94,69 \\
\hline 2. & Flexible use of monopoly & 93,93 \\
\hline 3. & Cell matter knowledge increases & 91,66 \\
\hline 4. & The use of monopoly for independent teaching & 86,36 \\
\hline 5. & Understanding of cell teaching materials increases & 85,60 \\
\hline 6. & Monopoly use to grow teaching interest & 83,33 \\
\hline 7. & The use of monopoly provides teaching a pleasure & 90,15 \\
\hline 8. & Display image composition and colour matching & 86,36 \\
\hline 9. & Communicative language & 81,87 \\
\hline 10. & The use of monopoly trigger motivation & 89,39 \\
\hline 11. & Monopoly use sharpens memory & 81,87 \\
\hline 12. & Evaluation questions are easy to understand & 81,81 \\
\hline 13. & Monopoly app is interesting & 81,87 \\
\hline
\end{tabular}

Based on table 8, the results of student responses to products with the highest percentage acquisition above 90\% are:

1. Monopoly educational game application is easy to use.

2. Monopoly educational game applications can be used anywhere.

3. The monopoly educational game application makes it easier and increases students' knowledge regarding cell teaching material.

4. Monopoly educational game applications make a fun atmosphere in the teaching process.

Simultaneously, the lowest percentage acquisition of $81.81 \%$ was the evaluation questions presented in the monopoly educational game application that students did not understand. Monopoly games have several advantages over other teaching media, namely: 1) making teaching more efficacious [19], 2) increasing students' critical thinking skills [20], 3) increasing motivation [21], 4) increasing understanding [22], 5) develop skills, 6) provide a pleasant teaching experience [11] [6] [23], 7) develop good attitudes of students such as; students value the opinions of others more, students can work together well, students are brave in expressing opinions and students can appreciate differences in character [24][25].

\section{CONCLUSION}

It can be concluded that the monopoly educational game application gets a "feasible" rating from linguists, "very feasible" from teaching material experts and media specialists. The product was assessed as high quality and attractive based on the biology teacher and students' responses after being tested. The teacher can use this product as a medium of teaching to make teaching and teaching activities more interactive and fun. It can be used for repeated teaching anywhere and anytime to increase their knowledge of cell teaching material for students. The next researcher is expected to try out the product to determine its effectiveness in the teaching process.

\section{AUTHORS' CONTRIBUTIONS}

1, 2, 3 and 4 contributed to the design research. 1contributed to the implementation of the research, to the analysis of the result and to the writing of the manuscript. 2, 3 and 4 contributed providing criticism, suggestions, helped result analysis and correction of manuscript.

\section{ACKNOWLEDGMENTS}

The researcher would like to thank the supervisors and all parties at SMA YP Unila Bandar Lampung who helped complete this article.

\section{REFERENCES}

[1] T. P. Herdani, N. Sartono, D. Evriyani, Pengembangan permainan monopoli termodifikasi sebagai media pembelajaran pada materi sistem hormon (penelitian dan pengembangan di SMA Jakarta), in: R. H. Ristanto (eds) Biosfer: Jurnal Pendidikan Biologi, vol 8(1), Universitas Negeri Jakarta, Jakarta, 2015, pp. 20-28.

[2] S. Adam, M. T. Syastra, Pemanfaatan media pembelajaran berbasis teknologi informasi bagi siswa kelas XI SMA Ananda Batam, in: LPPM Universitas Putera Batam (eds) CBIS Journal: Computer Based Information System Journal, vol 3(2), Universitas Putera Batam, Kepulauan Riau, 2015, pp. 78-90.

[3] N. Apriyanti, R. A. Razaq, M. S. Nizam, Shaharom, S. S. A. Rahim, S. H. Halili, Need analysis of infographic media using technology for learning physics, in: S. TOKER (eds) Malaysian Online Journal of Educational Technology, Malaysia, vol 8(1), 2020, pp. 48-62. http://dx.doi.org/10.17220/mojet.2020.01.004.

[4] T. Tafonao, Peranan media pembelajaran dalam meningkatkan minat belajar mahasiswa, in: $\mathrm{K}$. 
Rahman (eds) Jurnal Komunikasi Pendidikan, vol 2(2), Universitas Veteran Bangun Nusantara, Jawa Tengah, 2018, pp. 103-114.

[5] M. Safitri, R. Riandi, A. Widodo, W. R. Nasution, Integration of various technologies in biology learning, in: Proceeding of International Conference on Mathematics and Science Education (ICMScE), IOP Publishing, Britania Raya, 2017, pp. 1-4. doi :10.1088/1742-6596/895/1/012145.

[6] I. Maryani, Z. Sumiar, Developing science monopoly on the force learning material for elementary school students, in: M. N. Wangid (eds) Jurnal Prima Edukasia, vol 6 (1), Universitas Negeri Yogyakarta, Yogyakarta, 2018, pp. 11-20, DOI: http://dx.doi.org/10.21831/jpe.v6i1.16084

[7] A. Firmansyah, S. Indana, Developing biologybased monopoly game as media to enhance student's learning outcome and social ability, in: W. Strielkowski (eds) Proceeding Advances in Social Science, Education and Humanities Research (ASSEHR), Atalntis Press, Paris, vol 108, 2018, pp. 218-222

[8] M. S. Vásquez, M. Peñafiel, A. Cevallos, J. Zaldumbide1, D Vásquez, Impact of game-based learning on students in higher education, in: International Conference on Education and New Learning Technologies, Barcelona, Spain, 2017, pp. 1-8. DOI: 10.21125/edulearn.2017.1942.

[9] S. L. Wicaksono, E. Wahyuno, U. Kustiawan, Penggunaan permainan monopoli dalam pembelajaran matematika pada siswa tunagrahita ringan, in: R. F. Pradipta (eds) Jurnal Ortopedagogia, vol 2(2), Universitas Malang, Malang, 2016, pp. 65-68.

[10] A. N. M. Fauziah, A. R. Purnomo, N. Fathonah, Khusaini, The use of monopoly-like game $(\mathrm{mlg})$ to promote qualified scores for three student competencies, in: Parmin (eds) Jurnal Pendidikan IPA Indonesia, vol 7(3), Universitas Negeri Semarang, Semarang, 2018, pp. 280-285. DOI: 10.15294/jpii.v6i2.8183

[11] F. Agustiya, A. Sunarso, S. Haryani, Influence of CTL model by using monopoly game media to the student's motivation and science learning outcomes, in: S. Haryani (eds) Journal of Primary Education, vol 6(2), IKIP Siliwangi, Jawa Barat, 2017, pp. 114-119.

[12] K. Ulfa, L. Rozalina, Pengembangan media pembelajaran monopoli pada materi sistem pencernaan di SMP, in: Y. T. Samiha (eds) Bioilmi: Jurnal Pendidikan, vol 5(1), Universitas
Islam Negeri Raden fatah Palembang, Sumatra Selatan, 2019, pp. 10-22.

[13] A. Maghfiroh, Efektivitas penggunaan permainan monopoli pada materi sistem ekskresi sebagai media pembelajaran teams games tournament (tgt) terhadap hasil belajar siswa kelas XI SMAN 11 Semarang, Universitas Islam Negeri Walisongo, 2016

[14] Gall, Borg, Educational research , an introduction, Longman Inc, 1983

[15] S. Arikunto, Evaluasi Program Pendidikan, Bumi Aksara, 2014

[16] M. Grozdanovic, D. Marjanovic, G. L. Janackovic, M. Djordjevic, The impact of character/background colour combinations and exposition on character legibility and readability on video display units, in: F. L. Lewis (eds) Transactions of the Institute of Measurement and Control, United Kingdom, vol 39(10), 2017, pp. 1454-1465. DOI: $10.1177 / 0142331216640601$.

[17] A. Zorko, S. I. Valenko, M. Tomiša, D. Keček, D. Čerepinko, The impact of the text and background color on the screen reading experience, in: Technical Journal, vol 11(3), 2017, pp. 78-82.

[18] R. A. Nurdini, The use of picture to improve students' english speaking skill Rahmi, in: D. May (eds) IJET: International Journal of Emerging Technologies in Learning, Germany, vol 7(2), 2018, pp. 157-162

[19] Y. Mulyawati, R. A. Ghani, Comparison of ips learning results using monopoly media and power point media, in: H. Suharyati (eds) JHSS: Journal of Humanities and Social Studies, vol 3(2), Universitas Pakuan, Bogor, 2019, pp. 86-89.

[20] M. R. D. Dirgantara, S. M. E. Susilowati, P. Marwoto, The Use of Monopoly Media to Improve Primary Student's Critical Thinking Skills in Science Learning, in: S. Haryani (eds) Journal of Primary Education vol 8(3), Universitas Negeri Semarang, Semarang, 2019, pp: 262-269. DOI https://doi.org/10.15294/jpe.v8i3.26652.

[21] V. R. Hidayah, Monopoly science as a medium of biological learning (kingdom animalia material) in disruption era, in: Lukman (eds) IJECA: International Journal of Education and Curriculum Application, vol 1(2), Universitas Muhammadiyah Mataram, Nusa Tenggara Barat, 2018, pp. 84-89. https://doi.org/10.31764/ijeca.v1i2.2145

[22] M. A. Maulyda, V. R. Hidayati, M. Erfan, Monopoly game media as an effort to improve calculation problem solving ability in elementary 
school students, in: M. G. Ristiana (eds) JIML: Journal of Innovative Mathematics Learning, vol 3(4), IKIP Siliwangi, Jawa Barat, 2020, pp. 199207.

[23] S. B. Shanklin, C. R. Ehlen, Extending the use and effectivenes of the monopoly ${ }^{\circledR}$ board game as an in-class economic simulation in the introductory financial accounting course, in: American Journal of Business Education, United States, vol 10(2), 2017, pp. 75-80.

[24] G. D. S. Rahayu, H. S. P. Arga, Influence of vbabased monopoly game in microsoft excelas teaching materialon primary school students' crosscultural competencein social studies learning, in: J.
Julia (eds) Mimbar Sekolah Dasar, vol 6(2), Universitas Pendidikan Indonesia, Bandung, 2019, pp. 147-159. Doi: 10.17509/mimbarsd.v6i2.16935.

[25] E. Syalfifi, M. S. Sumantri, D. Yatima, Implementation of word monopoly as a learning media to improve creative and moral attitudes in the students of class IV students in grade IV of SDN Srengseng sawah 15 pagi, in: R. Pavlović (eds) American Journal of Educational Research, United States, vol 7(1), 2019, pp. 97-103. DOI:10.12691/education-7-1-15. 